\title{
Cadmium in seawater recorded by mussels: regional decline established
}

\author{
Helmut Fischer
}

Ohlandbogen 9. D-2300 Altenholz, Federal Republic of Germany

\begin{abstract}
The mussel Mytilus edulis is used as a quantitative indicator of dissolved cadmium in the water of the Kieler Förde in comparison with a reference site in the Kieler Bucht (Western Baltic Sea). As recorded by the mussel, the baseline Cd concentration in the Kieler Bucht declined from ca $65 \mathrm{ng} \mathrm{l}^{-1}$ in 1980 to $35 \mathrm{ng}^{-1}$ in 1984. Recaiculations of literature data suggest that the 1975-1976 Kieler Bucht level was ca $110 \mathrm{ng}^{-1}$ The 'normal' distribution of dissolved $\mathrm{Cd}$ in the Kieler Förde was characterized by ca $140 \%$ of the baseline in the harbour area, $85 \%$ in the inner fjord, and 120 to $140 \%$ in the outer fjord. Other patterns indicated by the mussel are considered to reflect occasional coincidence of hydrographic stagnation and specific events (harbour dredging, sewage pollution, industrial discharges). After collapses of oxybiotic life the mussel indicated approximately half normal Cd levels, but there is doubt that 'mussel watch' records may be relied upon if the mussels had been affected by anoxic conditions. 'Mussel watch' estimates of chemical water quality documented a downward trend of dissolved Cd in the SW Kieler Bucht, which corresponds to the information available from analytical seawater chemistry. According to the regional hydrography, this is conceived to reflect a decline of dissolved Cd and possibly other metals on a broader geographical scale. Implications suggested relate to the following of natural fluxes in the management of chemically similar wastes.
\end{abstract}

\section{INTRODUCTION}

In 1973-1974, Karbe et al. (1977) performed a 'mussel watch' survey on trace elements in Mytilus edulis from German coastal waters. They found that the tissue levels of several trace metals (Ag, Cd, $\mathrm{Zn}$ ) were generally higher in samples from the Baltic shoreline than in those collected from the North Sea. A similar survey carried out by Theede et al. (1979; sampling 1975-1976) focussed on $\mathrm{Cd}$ in the mussel. Elevated concentration in soft tissue was also recorded for Baltic specimens. As a most spectacular result, analyses of mussel tissue indicated $\mathrm{Cd}$ contamination in the harbour of Kiel. This 'could not be confirmed' by data from another one-time survey carried out in 1979 (Möller et al. 1983).

To improve the basis for evaluating 'mussel watch' data in terms of environmental quality, problem-orientated research was considered necessary. Investigations on Cd in the mussel (Fischer 1983, 1986a, 1988) have reached a stage where it appears feasible to estimate the concentration of dissolved $\mathrm{Cd}$ in coastal marine environments from field surveillance data (Cd body burden and shell weight of the mussel) and information on salinity.

(c) Inter-Research/Printed in F. R. Germany
A concomitant monitoring programme has provided a data base which can be evaluated from the results of the research mentioned above. Some qualitative results have already been published, and discussed with respect to mechanisms of biological self-purification (Fischer 1986b).

This study attempts to provide a quantitative assessment of dissolved $\mathrm{Cd}$ in the Kieler Forde in comparison with a baseline established for the open Kieler Bucht, as derived from 'mussel watch' records in the period 1980 to 1984 . The new scientific basis has also been applied to the data of Theede et al. (1979) for recalculating hypothetical levels of dissolved Cd in 1975-1976.

Additional information has been sought from other sources (water chemistry, weather records and regional hydrography, communal administration, local industry) to substantiate the assessment of dissolved $\mathrm{Cd}$, and to identify possible reasons for specific events recorded by the mussel.

\section{Study area}

The Kieler Förde is a fjord-like embayment on the Baltic coast of the Federal Republic of Germany. It 


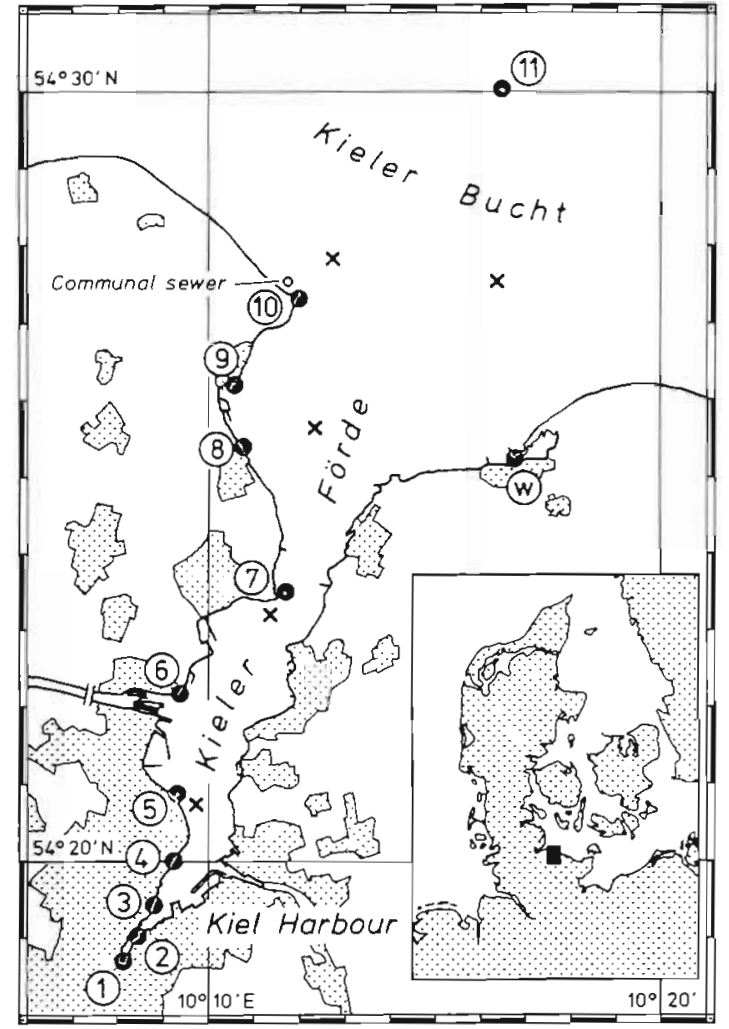

Fig. 1. Sampling sites in Kieler Förde, Western Baltic Sea Shaded: city of Kiel and suburbs. 1-3: Kiel harbour; 4-6: inner fjord; $7-10$ : outer fjord; 11: Kiel lighthouse; $W$ : shallow lagoon; $\mathrm{x}$ : navigational buoys used for suspending juvenile mussels

extends ca $17 \mathrm{~km}$ NNW and opens into the SW Kieler Bucht. The city of Kiel surrounds the inner fjord. Industrial areas are located at the Kieler Förde apex, and at the passage towards the outer fjord. A number of communal rainwater drainage outlets open directly into the inner fjord. Mixed industrial and domestic wastewater from Kiel and its suburbs (ca 300000 inhabitants) is purified in a treatment plant (mechanical treatment since 1972, biological since 1975, chemical since 1985), and released to the Kieler Bucht near sampling Site 10 (Fig. 1). Depending on the surface current, the sewage plume drifts ca $7^{\circ}$ right of the local wind and has a general tendency to parallel the shoreline.

Water depth in the Kieler Forde is 12 to $18 \mathrm{~m}$. Temperature (ca $0-17^{\circ} \mathrm{C}$ ) and salinity (winter $19 \%$, summer ca $15 \%$ ) follow the seasonal cycle in the Kieler Bucht. Between May and October the water column is stratified (Lenz 1981, his Fig. 5). There is virtually no tide, but fluctuation of ca $1 \mathrm{~m}$ in the water level occurs as a result of Baltic seiches and the overall meteorological situation (Magaard 1974).

Above all, water exchange in the Kieler Forde depends on the local surface wind. There are 2 extreme situations (Kändler 1960). (1) Winds from SE to W induce a surface current towards the Kieler Bucht, and a compensatory inflow of bottom water of North Sea origin advected through the Baltic approaches (Krug 1963. Struve-Blank 1982), which wells up in the inner fjord. In case of SSW storms, the water of the inner Kieler Förde may be completely exchanged within a few hours. (2) Periods of calm weather or winds from NW to E interrupt the water exchange. A slow inward drift of the uppermost water layer may advect Baltic surface water towards the inner fjord.

Due to the major importance of the local wind, meteorological records allow us to infer what hydrographic situation occurred during a particular period in the past.

\section{MATERIAL AND METHODS}

\section{Field and laboratory work}

Sampling. Kieler Bucht baseline: Mussels were dredged from a natural bed in the Eckernförder Bucht (centre of $1 \mathrm{n}$ mile haul: $54^{\circ} 31.4^{\prime} \mathrm{N} 10^{\circ} 00.5^{\prime} \mathrm{E}$, not covered by Fig. 1) at ca $6 \mathrm{~m}$ depth (subsurface water layer above the halocline). From December 1980 to August 1982, samples of 40 to 50 individuals over a wide size range were analysed (regression analysis of log-transformed data). Later, 10 to 15 individuals of ca $30 \mathrm{~mm}$ shell length were selected (arithmetic means, Fischer 1983)

Kieler Förde: Ten to 15 mussels each of ca $30 \mathrm{~mm}$ shell length were collected in 1.5 to $2 \mathrm{~m}$ depth from wooden pilings (surface water layer; Fig. 1). In summer 1984, juveniles were suspended from navigational buoys (additional test on the influence of TBT-antifouling paint: no effect on $\mathrm{Cd}$ accumulation), and retrieved after 2 mo growth in their new environment (importance of growth: Fischer 1988).

Sample processing and analysis. Fouling organisms were removed from the shells, and mussels were placed in clean seawater to allow elimination of gut contents. The mussels were killed by wet heat at $60^{\circ} \mathrm{C}$, and the water was drained. Some samples were sealed in polyethylene bags and stored in a deep freezer until required.

Mussels were treated individually. After shucking, the shells were dried overnight, weighed, and measured for length. The soft tissues were freeze-dried, oven-dried, and weighed. Soft tissues were ground to a powder, and 20 to $60 \mathrm{mg}$ subsamples were digested with a 1:1 mixture of concentrated nitric acid and perchloric acid. The remaining soft-tissue powder was sealed in glass vials, and preserved to allow replicate analyses. The shells were also stored. 
Cd was analysed by graphite funnel atomic absorption spectroscopy; Merck $^{\circledR}$ standard solutions were used for calibration. (The same analytical technique was used by Theede et al. 1979.)

Analytical quality control. From 1984 on, marine biological reference material TORT-1 (National Research Council, Ottawa) was used to provide analytical quality control. Results submitted within the frame work of the ICES 7 th intercalibration for trace metals in biological tissue (Part 2) were within the consensus values (Berman \& Boyko 1987), but Cd analyses done in Part 1 of that exercise had been precise but 25 to $32 \%$ too low (Berman \& Boyko 1986). Replicate analyses were performed on stored samples relating to 1980 to 1983 . No significant deviations were detected, with the exception of an equivalent bias in one data set (November 1983) which had been analysed together with the ICES 7/TM/ BT (Part 1) samples (all analyses repeated).

\section{Quantitative assessment}

Scientific basis. Much of the variability in (conventional) tissue concentration data on heavy metals in molluscs results from temporal fluctuation and spatial differences of soft-tissue weight. With respect to cumulative contaminants in conchiferous molluscs, this source of variability can be eliminated by relating the soft-tissue contaminant burden to the weight of the shells - an approach exemplified on $\mathrm{Cd}$ in the mussel (Cd/shell-wt index, Fischer 1983).

Within the range of 15 to $35 \%$, the $\mathrm{Cd} /$ shell-wt index of the blue mussel is approximately inversely proportional to salinity (Fischer 1986a; linear regression of log-transformed original data: $\mathrm{b}=-1.1725$, $\mathrm{r}=$ -0.9236 )

Where the molar ratio of dissolved $\mathrm{Z}_{\mathrm{n}}$ to $\mathrm{Cd}$ remains in the (normal) range of $50: 1$ to $120: 1$, accumulation of $\mathrm{Cd}$ by the mussel is not significantly influenced by dissolved $\mathrm{Zn}$. Accumulation of $\mathrm{Cd}$ is proportional to dissolved $\mathrm{Cd}$, and a Cd/shell-wt index of $5 \mathrm{\mu g} \mathrm{g}^{-1}$ relates to mussels grown in $1 \mathrm{\mu g} \mathrm{l}^{-1}$ dissolved $\mathrm{Cd}$ and $15 \%$ salinity (Fischer 1988).
Calculations. Individual $\mathrm{Cd}$ body burden was not normalized to a standard specimen size. Cd concentration of mussels relates to the dry weight of soft tissues. A condition index (CI) is calculated in terms of soft tissues as a percentage of total dry weight. The results are presented in terms of arithmetic means and their $95 \%$ confidence intervals.

The level of dissolved $\mathrm{Cd}$ in seawater was estimated as recently suggested (Fischer 1988). The basic data required are: Cd burden of soft tissues $(\mu \mathrm{g})$, weight of the shells ( $g$ ), and average salinity of sampling site (\%o). Calculations are as follows: (1) Calculate the Cd/shellwt index ( $\mu \mathrm{g} \mathrm{g}^{-1}$ ); (2) multiply by experimental reference salinity $(15 \%$ ) and divide by average salinity of sampling site $(\%)$ to yield the (hypothetical) $\mathrm{Cd} / \mathrm{shell}$ wt index in $15 \%$; (3) divide this hypothetical index ( $\mu \mathrm{g}$ $\left.\mathrm{g}^{-1}\right)$ by the experimental reference value of $5\left(\mu \mathrm{g} \mathrm{g}^{-1} /\right.$ $\left.\mu \mathrm{g} \mathrm{l}^{-1}\right)$, which is the $\mathrm{Cd} /$ shell-wt index of mussels grown in $15 \%$ with $1 \mu \mathrm{g} \mathrm{l}^{-1}$ dissolved $\mathrm{Cd}$, to yield dissolved $\mathrm{Cd}\left(\mathrm{\mu g} \mathrm{l}^{-1}\right)$ of the natural environment. The mean salinity at the reference site 1 mo before sampling and above the halocline (Krey et al. 1978) was used to calculate the Kieler Bucht data. The assessment of $\mathrm{Cd}$ in the inner Kieler Forde was calculated with a $0.5 \%$ lower salinity.

Dissolved Cd levels in 1975-1976 were recalculated on the basis of data published by Theede et al. (1979). The Cd soft-tissue burden of mussels was derived from original mean values of soft-tissue concentration and soft-tissue weight. On the basis of mean shell length ( $\mathrm{mm}$ ), a hypothetical shell weight ( $\mathrm{mg}$ ) was estimated, using the equation

$$
\text { shell-wt }=a \text { shell length }{ }^{2.8}
$$

with coefficients a of 0.06 (Kieler Förde - same as August 1959: Boje 1965) or 0.1 (Kieler Bucht; Table 1). The (hypothetical) $\mathrm{Cd} /$ shell-wt index calculated from these data was recalculated for dissolved $\mathrm{Cd}$ as described above. Average winter salinity (18\%, Krey et al. 1978; cf. Fig. 2) was used to correct the Kieler Bucht estimates. Sampling in the Kieler Förde had been done in August 1975 (H. Theede pers. comm.). Therefore, summer salinity $(15 \%)$ was applied in relation to these data.

Table 1. Mytilus edulis. Interrelationship between weight (mg) and length (mm) of shells: shell-wt $=a$ shell length ${ }^{2.8}$. Grand means of arithmetic means and their $95 \%$ confidence intervals, number of samples evaluated ( $n=15$ to 20 each)

\begin{tabular}{lcccc|}
\hline Site & Depth & Substratum & Coefficient $a$ \\
\hline Kiel harbour (1) & & & $0.0601 \pm 0.0071$ & $(3)$ \\
Inner fjord (4) & $1.5-2 \mathrm{~m}$ & Wood & $0.0585 \pm 0.0085$ & $(3)$ \\
Outer fjord (7) & & & $0.0592 \pm 0.0081$ & $(3)$ \\
Kiel lighthouse (11) & $1.5-2 \mathrm{~m}$ & Concrete & $0.0586 \pm 0.0061$ & $(5)$ \\
Kieler Bucht & $6 \mathrm{~m}$ & Gravel & $0.1011 \pm 0.0064$ & $(13)$ \\
\hline
\end{tabular}




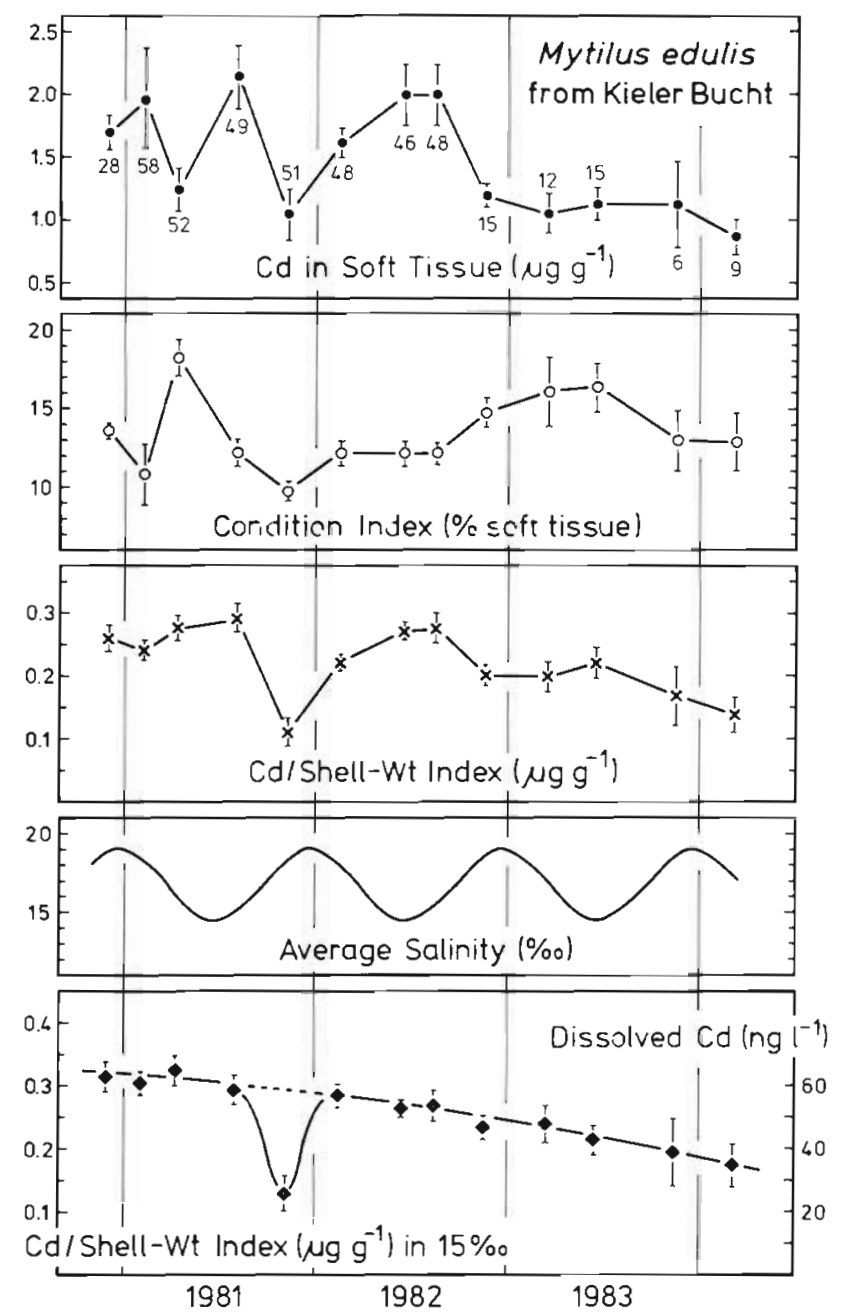

Fig. 2. Cd in Kieler Bucht as recorded by mussels. Cd softtissue concentration varies inversely with physical condition of mussels. This source of variability is eliminated by relating the soft-tissue $\mathrm{Cd}$ burden to weight of shells. Correcting the $\mathrm{Cd} /$ shell-wt index for seasonal fluctuation of salinity reveals a pronounced trend which indicates a decline of dissolved $\mathrm{Cd}$. A discontinuity was observed after anoxic conditions. $95 \%$ confidence intervals of means ( $n$ )

\section{RESULTS AND EVALUATION}

\section{Kieler Bucht cadmium baseline}

Observations 1980 to 1984

Monitoring data from a reference site in Kieler Bucht are summarized in Fig. 2, which also illustrates the successive steps towards a quantitative estimate of dissolved $\mathrm{Cd}$ in coastal seawater.

'Mussel watch' data collected in 1980-1981 gave the baseline concentration of $\mathrm{Cd}$ in the Kieler Bucht as ca

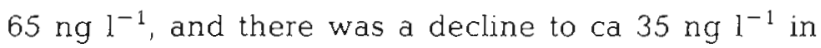
1984 .
Both an exceptionally low Cd level and a low CI of mussels were recorded in November 1981. This might be attributable to the influence of hydrogen sulfide (see evaluation of Kieler Förde data).

Retrospect to $1975-1976$

The data recalculated from Theede et al. (1979) indicate that the 1975-1976 level of Cd in the Kieler Bucht was higher than the 1980 to 1984 baseline. Data varied irregularly between sampling sites, and between subsamples differing in size of individual specimens. On the basis of lowest values indicated by the mussel, and least variability with individual size, a hypothetical baseline is estimated to have been ca $110 \mathrm{ng}^{-1}$ (Table 2). It relates to a site $3 \mathrm{n}$ miles SSW of the 1980 to 1984 reference station, on the same remote shoreline and in the same subsurface water layer (ca $6 \mathrm{~m}$ ).

\section{Evaluation}

According to the estimates derived from 'mussel watch' data, the level of dissolved $\mathrm{Cd}$ in the Kieler Bucht was ca $110 \mathrm{ng} \mathrm{l}^{-1}$ in 1975-1976. Ca $65 \mathrm{ng} \mathrm{l}^{-1}$ relate to 1980 , and there was a further decline to $35 \mathrm{ng}$ $1^{-1}$ in 1984 . This trend corresponds to the information available from seawater chemistry (Table 3). Data on $\mathrm{Cd}$ in communal sewage (Table 4 ) exemplify that the SW Kieler Bucht was considerably more contaminated with dissolved metals before industrial effluents became a matter of administrative control.

Assuming that these data reflect an average level in the upper $10 \mathrm{~m}$ of the Kieler Bucht as defined by Babenerd \& Gerlach (1987: ca $24 \mathrm{~km}^{3}$ ), ca $2500 \mathrm{~kg} \mathrm{Cd}$ would have resided in this water mass in 1975-1976, and ca $800 \mathrm{~kg}$ in 1984.

\section{Cadmium in the Kieler Förde}

Observations 1980 to 1984

Repetitive sampling of mussels from pilings along a transect of the Kieler Förde revealed a characteristic pattern of the Cd/shell-wt index (Fischer 1986b). Five data sets with overlapping $95 \%$ confidence intervals were recalculated for dissolved $\mathrm{Cd}_{1}$ and a grand mean of their arithmetic means and confidence intervals was calculated (Fig. 3a, shaded). There was also a temporal trend in these Kieler Förde data. Therefore, results were related to their respective Kieler Bucht values (Fig. 2) and plotted in terms of \% baseline (Fig. 3b). The shaded range represents the average level of dissolved $\mathrm{Cd}$ in Kieler Förde in relation to the Kieler Bucht. 
Table 2. Hypothetical baseline level of dissolved Cd in Kieler Bucht 1975-1976 as recorded by Mytilus edulis. Original data of Theede et al. (1979, italics) and derived mean values of shell weight, $\mathrm{Cd} /$ shell-wt index, and dissolved Cd. (Four rows relate to size classes mentioned in the text)

\begin{tabular}{|c|c|c|c|c|c|c|}
\hline Site & $\begin{array}{l}\text { Shell length } \\
\qquad(\mathrm{mm})\end{array}$ & $\begin{array}{l}\text { Tiss. } \\
\text { (g) }\end{array}$ & $\begin{array}{l}\mathrm{Cd} \text { conc. } \\
\left(\mu \mathrm{g} \mathrm{g}^{-1}\right)\end{array}$ & $\begin{array}{c}\text { Shell weight } \\
\text { (g) }\end{array}$ & $\begin{array}{c}\text { Cd/shell-wt } \\
\left(\mu g g^{-1}\right)\end{array}$ & $\begin{array}{l}\text { Diss. Cd } \\
\left(\text { ng l }^{-1}\right)\end{array}$ \\
\hline \multirow[t]{4}{*}{ Karlsminde $\left(54^{\circ} 29.3^{\prime} \mathrm{N}, 09^{\circ} 56.0^{\prime} \mathrm{E}\right)$} & 25.6 & 0.13 & 3.78 & 0.88 & 0.56 & 130 \\
\hline & 43.5 & 0.53 & 3.00 & 3.9 & 0.41 & 100 \\
\hline & 70.6 & 1.72 & 3.55 & 15 & 0.41 & 100 \\
\hline & 83.6 & 2.38 & 4.81 & 24 & 0.48 & 100 \\
\hline
\end{tabular}

Table 3. Chemical analyses of dissolved cadmium in Baltic surface water (Arithmetic means and $95 \%$ confidence intervals)

\begin{tabular}{|c|c|c|c|}
\hline Year & Area & $\mathrm{Cd}\left(\operatorname{ng}^{-1}\right)$ & Source \\
\hline 1972 & Baltic & $220 \pm 25(63)$ & Kremling (1973) \\
\hline $1975-1976$ & Kieler Bucht & 110 (average) & Kremling (unpubl.) \\
\hline $1977-1978$ & SW Kieler Bucht & $71 \pm 16(27)^{a}$ & Kremling et al. (1979) \\
\hline 1982 & Kieler Bucht & 30 & Kremling \& Petersen (1984) \\
\hline
\end{tabular}

Table 4. Cadmium in communal sewage and sewage sludge, and estimated Cd discharges to Kieler Bucht in relation to the sewage policy of the city of Kiel. Basic data: $60000000 \mathrm{~m}^{3} \mathrm{~d}^{-1}$ sewage released to Kieler Bucht, $20000 \mathrm{~kg} \mathrm{~d} \mathrm{~d}^{-1}$ (dry) residual sludge deposited ashore (a,b). Boldface: mean values

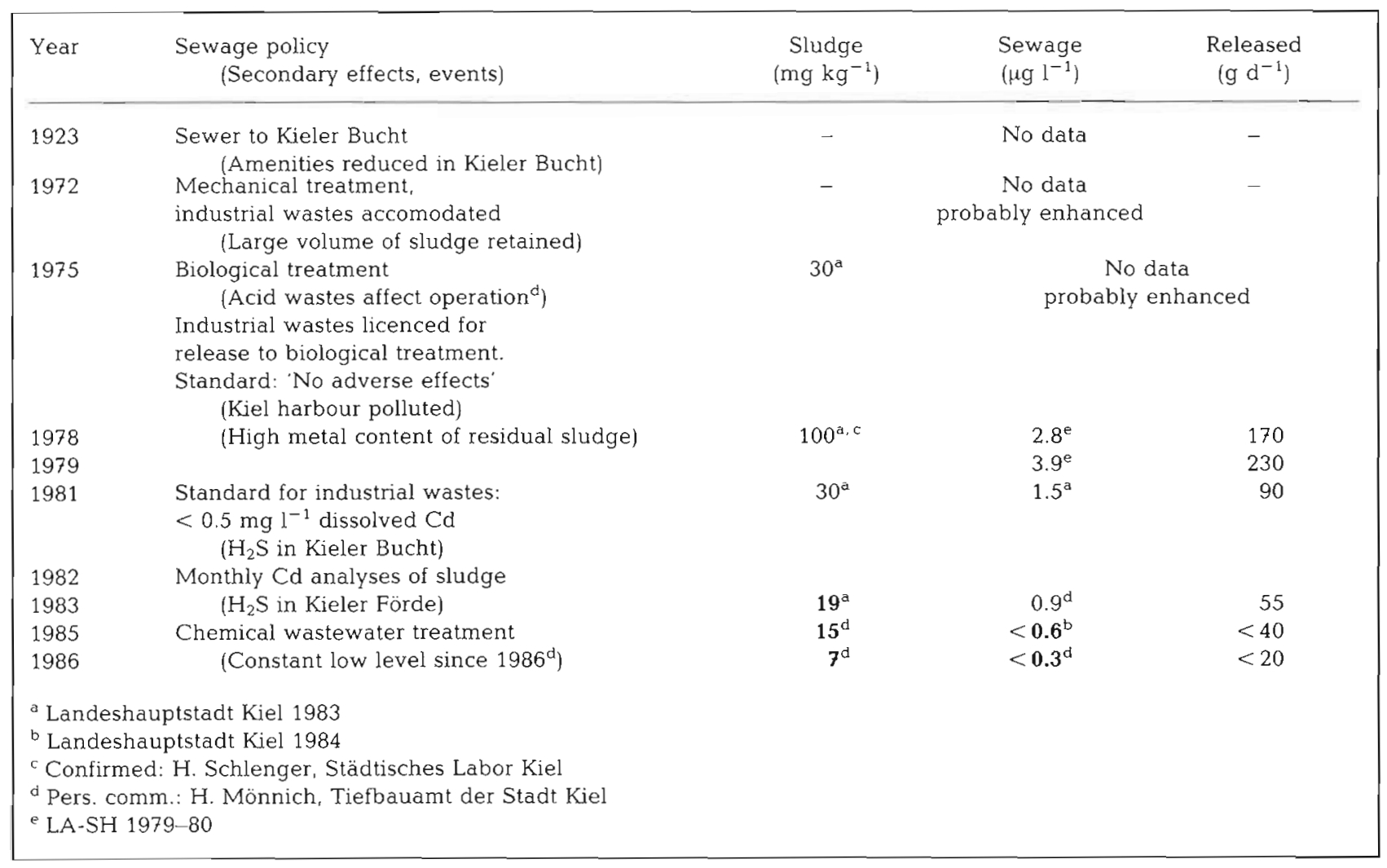



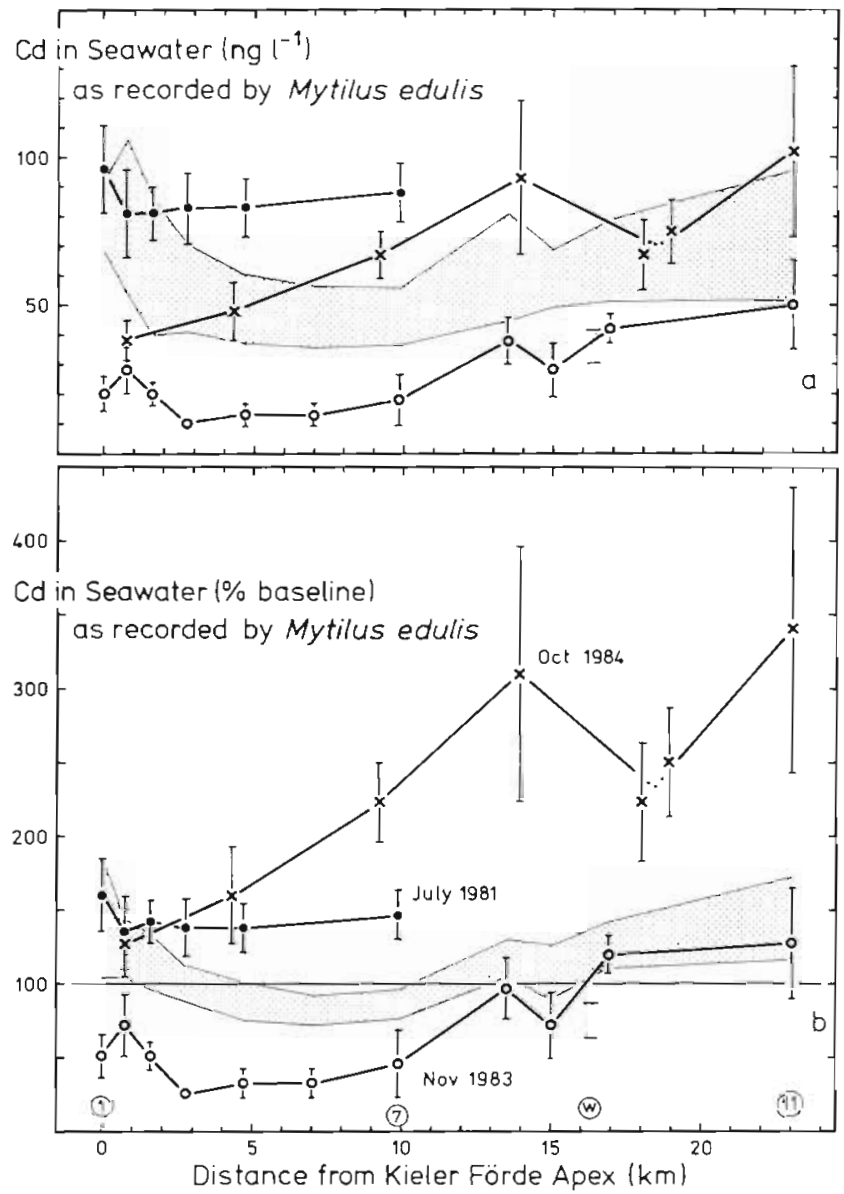

Fig. 3. Cd in Kieler Förde as recorded by mussels, in (a) $\mathrm{ng} \mathrm{l}^{-1}$ and (b) \% baseline. 'Normal' distribution of dissolved $\mathrm{Cd}$ (shaded) relates to intermittent water exchange. Some specific patterns observed after periods of little water exchange are attributed to harbour dredging (Jul 1981: $\bullet, n=15$ each), anoxic conditions (Nov 1983:, $\mathrm{n}=6$ each), and advection of contaminated surface water from the outer fjord $(x, n=7$ each). Bars: $95 \%$ confidence intervals of means. Shaded: grand mean of $95 \%$ confidence intervals ( 4 to 6 samples per site, $n=13$ to 15 each

As recorded by the mussel, the mean $\mathrm{Cd}$ concentration in the inner harbour (Sites 1 to 3) is ca 140 to $120 \%$ of the Kieler Bucht baseline. Average levels slightly lower than that reference are characteristic of the inner Kieler Förde (Sites 5 to 7 ), and lowest $\mathrm{Cd}$ levels were regularly recorded for a small lagoon on the outer fjord (W). In general, however, mussels from the outer fjord (Sites 8 to 11) indicated higher average Cd levels and greater variability in them.

Three of 8 transects were substantially different from the average pattern of 'mussel watch' records.

(1) In July 1981, mussels indicated that the Cd level had been ca $85 \mathrm{ng} \mathrm{l}^{-1}$ throughout the inner fjord (Fig. $3 a$ ), or ca $140 \pm 15 \%$ of the respective baseline
(Fig. 3b). The characteristic decline from the harbour area towards the inner fjord was absent.

(2) In November 1983, the dissolved Cd concentration indicated by mussels collected in the inner fjord was only 10 to $25 \mathrm{ng} \mathrm{l}^{-1}$ (Fig. 3a), or approximately half the 'normal' level (Fig. 3b). The CI of mussels was 8 to $11 \%$, which was ca 3 to $5 \%$ lower than expected according to the season

(3) In October 1984, there were 'normal' Cd levels of Ca $40 \mathrm{ng} \mathrm{l^{-1 }}$ in the harbour, and mussels had a $\mathrm{Cl}$ of $15 \%$ dry meat of total weight. Both variables increased towards the Kieler Bucht, where mussels collected from the surface water layer $(2 \mathrm{~m})$ indicated dissolved $\mathrm{Cd}$ concentrations as high as $100 \mathrm{ng} \mathrm{l}^{-1}$ (Site 11; confirmed by 2 further samples), and had a high physical condition $(\mathrm{Cl}>30 \%)$.

\section{Retrospect to $1975-1976$}

Estimates derived from the Theede et al. (1979) data suggest that the concentration of dissolved $\mathrm{Cd}$ in $\mathrm{Kiel}$ harbour was up to $1500 \mathrm{ng} \mathrm{I}^{-1}$ (Fig. 4). This is ca 15 times the Kieler Bucht level of that time, and ca 20 times the 'normal' concentration a decade later (shaded). There is a steep decline towards the basin of the inner fjord, and 1975-1976 baseline levels were recalculated for the passage to the outer fjord, at a distance of $10 \mathrm{~km}$ from the inner harbour.

\section{Evaluation}

Normal cadmium distribution 1980 to 1984: The normal range of dissolved Cd (Fig. 3, shaded) is conceived to represent an average situation where the water of the inner Kieler Forde is intermittently exchanged according to the local wind, and where no significant events occur. On the basis of a volume of ca $150 \times 10^{6} \mathrm{~m}^{3}$, and a Cd concentration of 35 to $50 \mathrm{ng} \mathrm{l^{-1 }}$ throughout (decline 1980 to 1984, Figs. 2 and 3), the inner Kieler Förde south of Site 7 (Fig. 1) contained ca 5 to $7.5 \mathrm{~kg} \mathrm{Cd}$. Somewhat higher average levels in the harbour area contribute less than $1 \%$ to the total balance since they relate only to a small volume $\left(<10^{6} \mathrm{~m}^{3}\right)$.

Monitoring data on Sites 5 to 7 indicate that the $\mathrm{Cd}$ concentration in the water was ca 4 to $8 \mathrm{ng} \mathrm{l}^{-1}$ lower than the Kieler Bucht reference (Fig. 3). These records, and corresponding data on a small lagoon (W), have been attributed to biological self-purification (Fischer 1986b). Assuming that Cd was uniformly distributed in the upper $6 \mathrm{~m}$ of the inner fjord (cf. Fischer 1983: Fig. 6) in an area of ca $100 \times 10^{6} \mathrm{~m}^{2}$, the observed difference would account for a net removal of ca. 250 to $500 \mathrm{~g}$ from 
the Cd amount in the inner fjord, in a dynamic equilibrium of all processes involved.

Higher average $\mathrm{Cd}$ levels and more fluctuation, as recorded for the outer fjord, are considered to result from moderate wastewater influence.

Different patterns 1980 to 1984: 'Mussel watch' records deviating from the normal $\mathrm{Cd}$ distribution (Fig. 3) have in common that they relate to periods dominated by little or onshore wind (cf. Deutscher Wetterdienst 1980 to 1984), i.e. by little water exchange. There were also hydrographically similar periods after which monitoring data were normal. Hence, specific events must have occurred in the differing cases.

(1) Information sought from communal authorities revealed that harbour dredging had been done in May 1981 (extraction of $142000 \mathrm{~m}^{3}$ muddy sediment, no other dredging operations during the period of this study; Hafenbauamt Kiel pers. comm.). Metals are partially remobilized upon resuspension and oxidation of marine sediments (Patchineelam \& Förstner 1977, Howell 1985). This suggests that a causal interrelationship existed with the July 1981 monitoring records. As indicated by the mussel, dissolved $\mathrm{Cd}$ exceeded the normal level by 30 to $40 \mathrm{ng} \mathrm{l}^{-1}$ throughout the inner fjord (Fig. 3). Uniform distribution of $\mathrm{Cd}$ in the upper $6 \mathrm{~m}$ would account for an additional amount of ca $3 \mathrm{~kg}$ - an amount corresponding to the total $\mathrm{Cd}$ content of $\mathrm{ca} 1000$ to $1500 \mathrm{~m}^{3}$ fine harbour sediment (unsieved, wet vol.: 2 to $3 \mathrm{~g} \mathrm{~m}^{-3} \mathrm{Cd}_{\text {i }}$ additional analysis for this study)

(2) 'Mussel watch' records from November 1983 indicated only ca half the normal Cd level. A similar observation relates to the Kieler Bucht (Fig. 2, November 1981). The 1981 data were assumed to reflect Cd depletion from anoxic bottom water (Fischer 1983, 1986b). This interpretation was probably false.

In both cases, sampling was done after collapses of oxybiotic life, and a poor $\mathrm{Cl}$ of mussels suggests that they had been affected by unfavourable conditions. In 1981, the odour of hydrogen sulfide had prompted to chemical analyses (M. Ehrhardt pers. comm.). Hence, the whole water column must have been saturated with $\mathrm{H}_{2} \mathrm{~S}$ although a few days later it was only detected in the bottom water (Ehrhardt \& Wenk 1984). The mussel would not grow under these conditions, but biological monitoring of cumulative contaminants requires growth of the indicator organism (Fischer 1988).

These considerations justify doubt in the reliability of those 'mussel watch' records, but there is no scientifically tested explanation for the analytical data to have been so exceptionally low. Further investigations are required, in particular with respect to the effect of $\mathrm{H}_{2} \mathrm{~S}$ both on the availability of metals to biota, and on the ability of organisms to retain them.

(3) An increase towards the outer fjord of both the $\mathrm{Cd}$ records and the $\mathrm{CI}$ of mussels, as in the October 1984 data, indicates a combined effect of industrial and domestic effluents extending from the Kiel communal sewage plant towards the inner fjord. Information on that plant (A. Heinke, communal laboratory, pers. comm.) suggests that metals, which are normally retained in the residual sludge, could have passed the system due to a case of irregular function in the biological stage (acid fermentation instead of anaerobic digestion). This event occurred in winter 1983 to 1984. Monitoring data relating to the surface water layer $13 \mathrm{~km} \mathrm{NW}$ of the communal sewer (Table 5) indicate that the SW Kieler Bucht had been considerably contaminated with Cd during the whole summer of 1984.

Contamination in summer 1975: Soft-tissue Cd concentrations as high as those documented by Theede et al. (1979; sampling: August 1975) were neither observed before (sampling 1973 to 1974; Karbe et al. 1977), nor in later surveys (sampling 1979: Möller et al. 1983; sampling 1980 to 1984: this study). It would be false, however, to question the August 1975 data for that reason.

Table 5. 'Mussel watch' records in 1984 at Boknis Eck, SW Kieler Bucht (54 32.9' N, $10^{\circ} 02.8^{\prime}$ E), $1.5 \mathrm{~m}$ depth. Mean values, $95 \%$ confidence intervals ( $\mathrm{n}$ )

\begin{tabular}{|c|c|c|c|c|c|}
\hline $\begin{array}{l}\text { Field } \\
\text { deployment }\end{array}$ & $\begin{array}{l}\text { Cd conc. } \\
\left(\mu g g^{-1}\right)\end{array}$ & $\begin{array}{l}\mathrm{CI} \\
(\%)\end{array}$ & $\begin{array}{c}\mathrm{Cd} / \text { shell-wt index } \\
\left(\mu g \mathrm{~g}^{-1}\right)\end{array}$ & $\begin{array}{c}\text { Salinity } \\
(\% 0)\end{array}$ & $\begin{array}{l}\text { Diss. Cd } \\
\left(\mathrm{ng} \mathrm{l}^{-1}\right)\end{array}$ \\
\hline 7 Jun to 6 Aug & $\begin{array}{r}3.61 \\
+0.61 \\
\text { (9) }\end{array}$ & $\begin{array}{r}25.3 \\
+\quad 1.8 \\
(8)\end{array}$ & $\begin{array}{r}1.22 \\
+\quad 0.22 \\
\text { (8) }\end{array}$ & 14.5 & $\begin{array}{r}236 \\
+\quad 42 \\
(8)\end{array}$ \\
\hline 6 Aug to 4 Oct & $\begin{array}{r}0.86 \\
\pm 0.11 \\
\text { (4) }\end{array}$ & $\begin{array}{r}33.5 \\
\pm \quad 1.8 \\
(11)\end{array}$ & $\begin{array}{r}0.43 \\
+0.04 \\
\text { (4) }\end{array}$ & 16.5 & $\begin{array}{r}95 \\
+8 \\
(4)\end{array}$ \\
\hline 4 Oct to $6 \mathrm{Dec}$ & $\begin{array}{r}0.71 \\
\pm 0.11 \\
\text { (5) }\end{array}$ & $\begin{array}{r}23.9 \\
\pm \quad 1.9 \\
(12)\end{array}$ & $\begin{array}{r}0.19 \\
\pm \quad 0.04 \\
(6)\end{array}$ & 18.5 & $\begin{array}{r}48 \\
+11 \\
(6)\end{array}$ \\
\hline
\end{tabular}




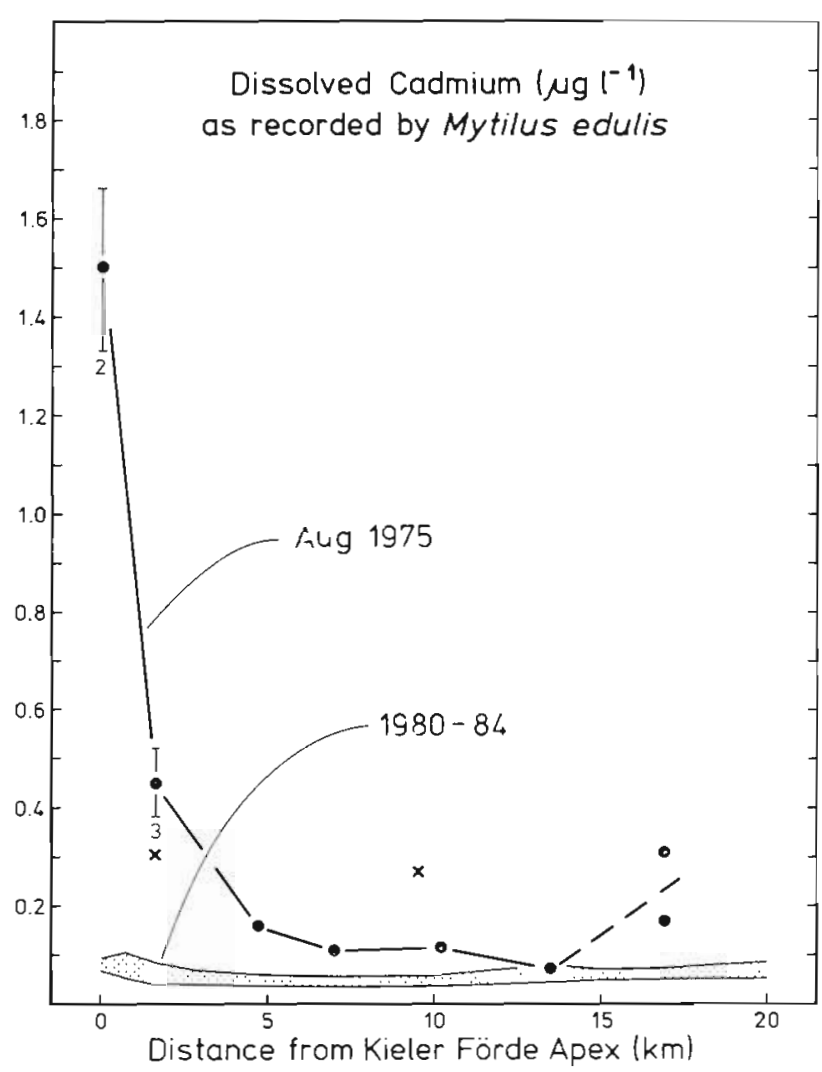

Fig. 4. Cd contamination in Kiel harbour as recorded by mussels. Hypothetical $\mathrm{Cd}$ levels recalculated from data of Theede et al. (1979) quantify the extent of contamination in summer 1975. Samples from the surface water layer $(\bullet)$, and from the bottom $(\mathrm{x})$. Bars: $95 \%$ confidence intervals of recalculated mean values, number of subsamples. Shaded: average Cd level 1980 to 1984 (this study)

There are chemical analyses on harbour water relating to the period before 1977, but the data were inconsistent and remained unpublished. Cd concentration had occasionally been as high as 600 to $800 \mathrm{ng}$ $\mathrm{I}^{-1}$ (K. Kremling, U. Rabsch pers. comm.). This is in the same order of magnitude as the recalculated 'mussel watch' data (Fig. 4). Assuming that an average $\mathrm{Cd}$ level of $400 \mathrm{ng} 1^{-1}$ applied to the upper $6 \mathrm{~m}$ of the harbour south of $54^{\circ} 20^{\prime} \mathrm{N}$ (ca $1.5 \mathrm{~km}^{2}$; Fig. 1), contamination in summer 1975 was ca 2 to $3 \mathrm{~kg} \mathrm{Cd}$ higher than the normal $1975 / 1976$ levels

Inquiries as to the possible causes revealed that a small electroplating plant released acid effluents through the communal rainwater drainage into the harbour of Kiel (pers. comm.. an administrator in charge, a chemical analyst, and the foreman of that plant). This does not exclude other sources, but no other information could be obtained (for a wider context cf. Table 4). It must be recognized that the prevailing wind in summer 1975 (Deutscher Wetterdienst
1975), before the mussels were sampled, inhibited water exchange of the inner fjord. It is concluded that the Theede et al. (1979) data reflect a coincidental occasion of industrial discharges, hydrographic stagnation, and a one-time 'mussel watch' survey.

\section{DISCUSSION}

\section{Methodological aspects}

The 'mussel watch' concept

The 'mussel watch' (Goldberg 1975) type of biological monitoring was proposed to circumvent technical difficulties of seawater chemistry, and to overcome the limited relevance of sporadic analyses to assess chemical seawater quality (Goldberg et al. 1978). The idea has been readily accepted in many parts of the world. This has been understood to reflect both the importance of that concept (Philipps \& Segar 1986), and a collective 'madness' in promoting and practising it before it had been sufficiently tested (White 1984).

Technical problems can be eliminated by technical advances, but there is an intrinsic dilemma in substitute approaches to unsolved problems: to confirm their significance, the problems must be solved - with the result that such indirect attempts may be outdated once they are proved to be sound. At present, there is more emphasis on the functional aspects of chemical speciation. Chemicals can only affect organisms if they are biologically available to them, which may be assessed by analysing the tissues of biological indicators (Waldichuk 1985, Goldberg 1986).

\section{Evolving a quantitative 'mussel watch' technique}

Within a narrow sector investigated by this author, the 'mussel watch' has been evolved to a stage where it appears workable with respect to its initial intentions. Methodological research done in advance started at the very basic question of an adequate independent variable (Fischer 1983). The scientific method was applied to several aspects (temperature, salinity, oxygen: Fischer 1986a; dissolved Zn and Cd: Fischer 1988), but additional information from natural environments was required to determine the relevance of experimental laboratory research for the real world (Fischer 1988: Table 3).

Reciprocal feedback with water chemistry

Information from analytical seawater chemistry has also been sought to substantiate the significance of 
the 'mussel watch' estimates of dissolved $\mathrm{Cd}$ presented here. Results of analyses on Baltic surface water relating to the period before 1977-1978, however, were later considered unreliable. High average values and wide fluctuation of analytical data were conceived to result from contamination during water sampling and sample processing - an assumption apparently confirmed by a coincidence between increased care and effort, and both lower analytical data and less variability in them (Kremling et al. 1987).

This study, including the investigations on possible causes of the differences in monitoring records, suggests that much of the higher levels and larger variability in the older data resulted from local and temporal fluctuation of wastewater influence (Horstmann 1972, Hubrich 1972) - both in seawater chemistry and 'mussel watch' surveys. The 'mussel watch' estimates of dissolved $\mathrm{Cd}$ published here were discussed with K. Kremling (Institut für Meereskunde, Kiel), and gave rise to re-examination of the older water chemistry data. It is now considered that only ca $10 \%$ decline can be attributed to technical advances in water sampling and processing (K. Kremling pers. comm.), which means that the 'mussel watch' records reported here correspond to water chemistry data.

\section{Regional assessment}

SW Kieler Bucht: decline of dissolved cadmium

A downward trend in the Cd baseline of the SW Kieler Bucht has become evident as a result of this study, and of the associated feedback of information between seawater chemistry and biological contaminant monitoring. One may assume an error of ca $20 \%$ in the 'mussel watch' estimates (this remains to be substantiated), but this would not detract from the existence of a remarkable decline.

Considering the water masses concerned, it is obvious that the reduction of local discharges cannot be the only reason for decreasing $\mathrm{Cd}$ levels in the SW Kieler Bucht. According to the regional hydrography, successively lower 'mussel watch' records must be conceived to reflect a decline of $\mathrm{Cd}$ (and probably of other metals as well) in seawater on a broader geographical scale. Such a decline reflects a shift in the relation between inputs to a water mass, and removal from it. In addition to lower metal inputs, this may be an indirect effect of eutrophication, in that stimulated productivity in a water mass increases rates of self-purification, and of metal accumulation in the sediments (discussed in Fischer 1986b).
Kieler Förde: impact related to hydrography

'Mussel watch' records and additional investigations reported here confirm that the regional hydrography determines the susceptibility of geographically defined environments to pollution. In inshore basins such as the Kieler Förde, interaction of hydrography and contamination results in unpredictably variable conditions. This means that occasional 'mussel watch' observations have little relevance in terms of environmental assessment, and cannot be confirmed (or rejected) by subsequent one-time surveys.

To assess contamination of inshore environments, a baseline must be established (United Kingdom Conference Secretariat 1987), and monitoring must be done at relatively small intervals over prolonged periods. As a by-product, occasional events may be detected and assigned to a relatively narrow time interval, provided the hydrographic situation was such that detectable impact occurred.

Some balance calculations have been done to outline the amount of $\mathrm{Cd}$ residing in the Kieler Forde, and to scale the dimensions of anthropogenic impact concluded to have occurred according to specific information from other sources. Evaluation of monitoring results is always retrospective, and there is considerable uncertainty in attempts at post-dated causation and quantification. Yet this must be tried if environmental assessment is to make sense as an initial step to environmental management.

\section{Implications to coastal management}

$\mathrm{Cd}$ records by the mussel reflect that sedimentation zones in inshore basins represent both a sink and a potential source of metals in seawater (Cole 1979). Remobilization is promoted where man interferes with the natural flux of particles, and of the metals associated with them, to the bottom. Nevertheless, high metal levels in sediments indicate that removal dominates the metal balance of these environments.

Geologically relevant sedimentation areas, viz. the anoxic basins of hydrographically stratified seas, appear particularly suitable for ultimate deposition of wastes such as sediments extracted from marine waterways, dredged spoils from harbours, and biologically digested sewage sludge, which pose an acute regional problem to land-based management. These wastes are a potential threat to fresh-water and soil because they often contain high loads of metals - due to the same mechanisms which remove those metals from biogeochemical cycling in the sea. On a geological time scale, biologically mediated accumulation of metals in marine sediments results in the formation of biogenic 
ores such as the Mansfeld (GDR) Kupferschiefer. (Their physico-chemical affinity suggests that lipophilic contaminants/mineral oil make a similar case.) On the other hand, there should be little danger to the marine environment if its natural sinks were utilized as a depository of chemically similar wastes.

Processes and fluxes in the sea, by which contaminants are removed from the biosphere and concentrated in natural sinks, may be conceived as a renewable resource to an ecologically compatible management of wastes. From this point of view, the decline in the SW Kieler Bucht $\mathrm{Cd}$ baseline reported here suggests that there might be an increasing capacity of the Baltic ecosystem to receive metallic wastes and clear them to the lithosphere. Such a 'digestive capacity' of the sea corresponds to the 'assimilative capacity' concept (Cairns 1977, Goldberg 1979, Pravdic 1985), accepting dispersal where it is inevitable but eliminating dilution from the conceptual goals.

Apart from developing the scientific basis and a practicable 'soft' technology, integrating the marine environment into the management of civilizational wastes depends on adequate instruments for prior testing and operational control. This study has shown that the 'mussel watch' has some potential to provide a reliable tool for this. It may be reasonable to develop this potential by further problem-orientated research.

Acknowledgements. Field and laboratory work was performed from 1981 to 1985 at the Institut für Meereskunde an der Universität Kiel, in the frame of a research project supported by the Umweltbundesamt (UBA F \& E-Vorhaben Wasser 10607033 ). Full scope was granted by Prof. M. Theede, and technical assistance was ably provided by Ute Nissen (1981-1983), Monika Westphal (1983-1984), and Silke v. Bismark (1984-1985). This is gratefully acknowledged. Further effort depended, above all, on the support and patience of the author's family. This is to document the importance of that support, and to express my sincere thanks to my wife, Mrs Uta Fischer

\section{LITERATURE CITED}

Babenerd, B., Gerlach, S. (1987). Bathymetry and sediments of Kieler Bucht. In: Rumohr, J., Walger, E., Zeitzschel, B (eds.) Seawater-sediment interactions in coastal waters. An interdisciplinary approach. Springer, Berlin, p. 16-31

Berman, S. S., Boyko, V J. (1986). ICES seventh round intercalibration for trace metals in biological tissue, 7/TM/BT (Part 1). Int. Counc. Explor Sea Coop. Res. Rep. 138

Berman, S. S., Boyko. V. J. (1987). ICES seventh round intercalibration for trace metals in biological tissue, 7/TM/BT (Part 2). Preliminary report. National Research Council, Ottawa

Boje, R. (1965). Die Bedeutung von Nahrungsfaktoren für das Wachstum von Mytilus edulis L. in der Kieler Förde und im Nord-Ostsee-Kanal. Kieler Meeresforsch. 21: 81-100

Cairns, J. (1977). Quantification of biological integrity, In.: Ballantine R. K., Guarraia, L. J. (eds.). The integrity of water. United States Environmental Protection Agency, Washington, p. 171-187
Cole, H. A. (1979). Marine pollution - facts and fiction, the situation in Britain. Ocean Mgmt 5: 263-278

Deutscher Wetterdienst (1975). Täglicher Wetterbericht D 20873 A. Deutscher Wetterdienst - Zentralamt Offenbach, 100. Jahrgang, Nr 182-243

Deutscher Wetterdienst (1980 to 1984). Täglicher Wetterbericht D 20873 A. Deutscher Wetterdienst - Zentralamt Offenbach, 105.-109. Jahrgang

Ehrhardt, M., Wenk, A. (1984). Wind pattern and hydrogen sulfide in shallow waters of the Western Baltic Sea, a cause and effect relationship? Meeresforsch. 30: 101-110

Fischer, H. (1983). Shell weight as an independent variable in relation to cadmium content of molluscs. Mar Ecol. Prog Ser 12: $59-75$

Fischer, H. (1986a). Influence of temperature, salinity, and oxygen on the cadmium balance of mussels Mytilus edulis. Mar Ecol. Prog. Ser. 32: 265-278

Fischer, H. (1986b). Cadmium in Kieler Förde mussels: an innovative monitoring programme. Rapp. P.-v. Réun. Cons. Perm. int. Explor. Mer 186: 468-474

Fischer, H. (1988). Mytilus edulis as a quantitative indicator of dissolved cadmium. Final study and synthesis. Mar. Ecol. Prog. Ser. 48: 163-174

Goldberg, E. D. (1975). The mussel watch - a tirst step in global marine monitoring. Mar. Pollut. Bull. 11. 111

Goldberg, E. D. (ed.) (1979). Assimilative capacity of U.S coastal waters for pollutants. United States National Oce anographic and Atmospheric Administration, Washington

Goldberg, E. D. (1986). The mussel watch concept. Envir Monitg Assessmt 7: 91-103

Goldberg, E. D., Bowen, V T., Farrington, J. W., Harvey, G. Martin, J. H., Parker, P. L., Riesebrough, R. W., Robertson, W., Schneider, E., Gamble, E. (1978). The mussel watch Envir. Conserv. 5: 101-125

Horstmann, U. (1972). Über den Einfluß von häuslichem Abwasser auf das Plankton der Kieler Bucht. Kieler Meeresforsch. 28: 178-198

Howell, R. (1985). The effect of bait-digging on the bioavailability of heavy metals from surficial intertidal marine sediments. Mar. Pollut. Bull. 16: 292-295

Hubrich, L. -M. (1972). Zur horizontalen Ausbreitung von kontinuierlichen Abflüssen in das Küstenmeer - am Beispiel einer Abwassereinleitung in die Kieler Forde. Kieler Meeresforsch. 28: 162-177

Kändler R. (1960). Typen der Salzgehalts- und Temperaturschichtung in der Kieler Förde. Kieler Meeresforsch. 16 $164-179$

Karbe, L., Schnier, C., Siewers, H. O. (1977). Trace elements in mussels (Mytilus eduis) from coastal areas of the North Sea and the Baltic. Multielement analyses using instrumental neutron activation analysis. J. radioanal. Chem. 37: $927-943$

Kremling, K. (1973). Voltammetrische Messungen über die Verteilung von Zink, Cadmium, Blei und Kupfer in der Ostsee. Kieler Meeresforsch. 29: 77-84

Kremling, K., Brügmann, L., Jensen, A. (1987). Trace metals in the Baltic. In: Baltic Marine Environment Protection Commission (ed.) First periodic assessment of the state of the marine environment of the Baltic Sea area, 1980-1985; background document. Baltic Sea Environment Proceedings $17 \mathrm{~B}$, p. $82-130$

Kremling, K., Otto, C., Petersen, H. (1979). SpurenmetallUntersuchungen in den Förden der Kieler Bucht. Ber. Inst. MeeresKde Kiel 66: 1-38

Kremling, K., Petersen, H. (1984). Synoptic survey on dissolved trace metal levels in Baltic surface waters. Mar Pollut. Buil. 15: 329-334 
Krey, J., Babenerd, B., Lenz, J. (1978). Beobachtungen zur Produktionsbiologie des Planktons in der Kieler Bucht: 19571975. 1 Datenband. Ber Inst. MeeresKde KKiel 54: 1-113

Krug, J. (1963). Erneuerung des Wassers in der Kieler Bucht im Verlaufe eines Jahres am Beispiel 1960/61 Kieler Meeresforsch. 19: 158-174

LA-SH (Landesamt für Wasserhaushalt und Küsten des Landes Schleswig-Holstein) (1979-80). Gewässcrüberwachung 1978-79. LA-SH, Kiel

Landeshauptstadt Kiel (1983). Bericht über die Wertung des Schwermetalls Cadmium und Beurteilung der Analysenergebnisse über den Schwermetallgehalt im Bereich der Kläranlage Bülk. Der Magistrat, Tiefbauamt, Abt Stadtentwässerung, Az. 66.3-Dr. M/W - v. 7.1. $1982 \mathrm{mit}$ 8. Nachtrag v. 31.5.83

Landeshauptstadt Kiel (1984). Klärwerk Kiel in Bülk (communal brochure)

Lenz, J. (1981). Phytoplankton standing stock and primary production in the Western Baltic. Kieler Meeresforsch. Suppl. 5: 29-40

Magaard, L. (1974). Wasserstandsschwankungen und Seegang. In: Magaard, L., Rheinheimer, G. (eds.) Meereskunde der Ostsee. Springer, Berlin, p. 67-75

Möller, H., Schneider, R., Schnier, C. (1983). Trace metals and PCP content of mussels (Mytilus edulis) from the Southwestern Baltic Sea. Int. Rev. ges. Hydrobiol. 68: 633-647

This article was submitted to the editor
Patchineelam, S. R., Forstner, U. (1977). Bindungsformen von Schwermetallen in marinen Sedimenten. Untersuchungen an einem Sedimentkern aus der Deutschen Bucht. Senckenberg. marit. 9: 75-104

Phillips, D. J. H., Segar, D. A. (1986). Use of bio-indicators in monitoring conservative contaminants: programme design imperatives. Mar. Pollut. Bull. 17: 10-17

Pravdić, V. (1985). Environmental capacity - is a new scientific concept acceptable as a strategy to combat marine pollution? Mar Pollut. Bull. 16: 295-296

Struve-Blank, S. (1982). Die Strömungen in der Kieler Bucht. Ber. Inst. MeeresKde Kiel 102: 1-112

Theede, H., Andersson, I, Lehnberg, W. (1979). Cadmium in Mytilus edulis from German coastal waters. Meeresforsch. $27 \cdot 147-155$

United Kingdom Conference Secretariat (ed.) (1987). Quality status of the North Sea. Report by the Scientific and Technical Working Group for the Second International Conference on the Protection of the North Sea. Department of the Environment, London

Waldichuk, M. (1985). Biological availability of metals to marine organisms. Mar. Pollut. Bull. 16: 7-11

White, H. H. (1984). Mussel madness: use and misuse of biological monitors of marine pollution. In: White, $H$. $H$. (ed.) Concepts in marine pollution management. Maryland Sea Grant College, College Park, Md 20742, p. 325-337

Manuscript first received: September 19, 1988

Revised version accepted: May 22, 1989 